\title{
Caucasian clover as a pasture legume for dryland dairying in the coastal Bay of Plenty
}

\author{
R.N. WATSON ${ }^{1}$, F.J. NEVILLE ${ }^{1}$, N.L. BELL ${ }^{1}$ and S.L. HARRIS ${ }^{2}$ \\ ${ }^{1}$ AgResearch, Ruakura Agricultural Research Centre, Private Bag 3123, Hamilton \\ ${ }^{2}$ Dairying Research Corporation, Private Bag 3123, Hamilton
}

\begin{abstract}
The ability to spread underground through rhizomes, retention of a strong tap-root and a reputation for pest and disease tolerance, make caucasian clover (Trifolium ambiguum Bieb.) (CC) an attractive possibility for improving legume performance in coastal Bay of Plenty dryland dairying pasture. Large plots (0.125 ha) of Grasslands Kopu white clover (T. repens) (WC) and Endura CC were sown in spring (September 1994) as pure species swards following maize cropping and all but one $7 \mathrm{~m}$ wide strip undersown with ryegrass (Lolium perenne) in the following winter (July 1995). From September 1995, subplots within pure clover and undersown areas were treated with nematicide (oxamyl, fenamifos) and fungicide (metalaxyl, prochloraz) and mown to coincide with dairy cow grazing for determination of herbage yield. By the second spring, growth rates of CC matched those of WC and were superior by up to $60 \%$ through the second summer resulting in $9 \%$ greater total yield for $\mathrm{CC}$ pastures. Accumulated yield of CC pasture from September 1995 to June 1996 was significantly greater than WC (11.8 and $10.9 \mathrm{t} \mathrm{DM} /$ ha respectively). Caucasian clover was less responsive than WC to nematicide and fungicide treatment. With the methods used, CC can be established and perform well by the second year under dairy grazing in warm northern regions, and may provide for better summer production than WC. No difference was observed between the clover species in acceptability or pasture utilisation by dairy cows.
\end{abstract}

Keywords: dryland dairying, northern New Zealand, pasture establishment, pasture growth, pesticide responses, Trifolium ambiguum, Trifolium repens

\section{Introduction}

In the coastal Bay of Plenty (latitude $37-38^{\circ}$ S) white clover (Trifolium repens L.) (WC) presence in pasture is seasonally variable owing to the combined effects of summer drought and pests, particularly plant-parasitic nematodes (Watson et al. 1994). Hot dry summers on light volcanic ash soils, with concurrent seasonal overgrazing, lead to surface temperatures lethal to WC stolons and crowns (Watson et al. 1996a). Nematodes exacerbate this clover loss by weakening the root system and by delaying autumn recovery. Clover deficiency in pasture can be extended across successive years, with lost nitrogen inputs from $\mathrm{N}$-fixation, pasture production and forage quality. To alleviate this problem a clover able to spread underground, rather than from surface stolons, was considered to have potential for more reliable summer survival and autumn recovery. Caucasian clover (T. ambiguum Bieb.) (CC) represents a perennial pasture legume with good persistence (Strachan et al. 1994; Virgona \& Dear 1996) and high forage quality similar to that of WC (Peterson et al. 1994). However, it has not been evaluated under dairying, or in warmer and more northerly areas in New Zealand. Little is known of reactions of CC to pests and diseases characteristic of warmer areas of New Zealand.

The objectives of this work were to determine the growth characteristics of CC and compare this with WC under dairy grazing, and to determine the build-up of pests and diseases of each legume when established after long-term cereal cropping. Generally WC establishes with very high initial vigour after cereal crops, but begins to decline after the first year or so (Riley 1979). This is often attributed to changes in soil $\mathrm{N}$ status affecting competitive balance between grass and clover. However, many pests and diseases of clover are not hosted by cereal crops and build up after pasture establishment (Pederson et al. 1991).

\section{Methods}

The aim was to provide optimum management to suit the slow establishment of CC and use WC as a comparison. The site was on Paengaroa sandy soil from Kaharoa ash with a history of 15 years of continuous maize (Zea mays L.) cropping. The seed-bed was prepared by spraying with paraquat, removing maize stubble with a silorator, applying basal fertiliser, and cultivating with two shallow passes of a rotary hoe. Grasslands Kopu WC and Endura CC were sown through a roller drill as pure species swards in four replicate 0.125 ha plots on 24 September 1994. Lime- 
pelleted and inoculated seed was sown at $3.75 \mathrm{~kg} / \mathrm{ha}$ for WC (equiv. $3 \mathrm{~kg}$ bare seed, rhizobia strain CC275E) and at $12 \mathrm{~kg} / \mathrm{ha}$ for CC (equiv. $8 \mathrm{~kg}$ bare seed, $80 \%$ germination, rhizobia strain CC283B). The Cambridge roller was re-applied to the seed-bed after sowing although soil consolidation was poor. Further fertiliser, including $30 \mathrm{~kg} / \mathrm{ha} \mathrm{N}$, was applied in spring. Herbicide was applied in November 1994 for control of annual grass weeds. Clover seedlings were counted 2 weeks after sowing. Subplots $(5 \times 5 \mathrm{~m})$ with or without a nematicide treatment ( $5 \mathrm{~kg} / \mathrm{ha}$ oxamyl) were established in each main plot on 29 November 1994.

The experimental area was grazed in common by dairy cows with light on/off grazing in the first year starting in February 1995. A single strip from each subplot was mown before grazing for determination of herbage yields. On 22 July 1995 the plot area was undersown with $10 \mathrm{~kg} / \mathrm{ha}$ Yatsyn ryegrass, except for a $7 \mathrm{~m}$ wide strip across all plots maintained as a pure clover species sward. Further $5 \times 5 \mathrm{~m}$ subplots were set up on the undersown pasture and nematicide treatment was reapplied (28 September $5 \mathrm{~kg} / \mathrm{ha}$ fenamifos; 16 November $5 \mathrm{~kg} / \mathrm{ha}$ oxamyl). In addition all subplots were split treated with and without a fungicidal treatment ( $2 \mathrm{~kg} / \mathrm{ha}$ metalaxyl; $2 \mathrm{~kg} / \mathrm{ha}$ prochloraz). The subplots were fenced off and mown to coincide with grazing through the second growing season. Grazing was approximately 4 weekly to December 1995 and thereafter approximately 5-weekly to June 1996. Farm staff carefully observed for differences in response between the two clovers by dairy cows, and for differences in post-grazing herbage residuals.

$\mathrm{N}$-fixation activity to $7.5 \mathrm{~cm}$ soil depth was determined from grazed plot areas before grazing by the acetylene reduction method (Hoglund \& Brock 1978). At the same time $\mathrm{WC}$ and $\mathrm{CC}$ growing point density was determined from three random $5 \times 20 \mathrm{~cm}$ frame placements taken per plot. Further pesticide treatments were applied in autumn 1996 and basal fertiliser was applied to the subplots to compensate for herbage removal.

Changes in the abundance of soil nematodes, insect pests and pathogens were monitored throughout the study but are not reported in detail here. This paper reports on the growth performance of WC and CC over the first two years of establishment and general responses to pesticide applications. Data for the clover species, either combined or separately, were analysed by ANOVA with covariate adjustment for September 1995 plot yields applied from October 1995. $\log _{n}$ transformation was used for analysis of herbage yields, but this did not affect the interpretation of main effects and results from the untransformed analysis are presented.

\section{Results}

\section{Clover seedling establishment and growing point density}

Both clovers germinated well (CC and WC plots with $126 \pm 13 \mathrm{SE}$ and $150 \pm 8 \mathrm{SE}$ seedlings $/ \mathrm{m}^{2}$ respectively), and tap-roots developed to $30-40 \mathrm{~cm}$ depth 12 weeks after sowing and to $1 \mathrm{~m}$ depth by May 1995 . Plants were severely stressed by drought during November and December 1994 (2-monthly rainfall $41.7 \mathrm{~mm}$; soil moisture content reaching $6 \% \mathrm{M}_{\mathrm{w}}$ ). Patches became wilted, and in extreme cases only the central two leaves remained on $\mathrm{CC}$ crowns. With adequate subsequent moisture, WC growing point density increased rapidly through the first summer and autumn (Figure 1). The associated ground cover effectively suppressed weed growth. Growing point density continued to increase during spring 1995 to reach $1800 / \mathrm{m}^{2}$ by December. Growing point counts for CC remained significantly below those of WC on all assessments after November $1994(\mathrm{P}<0.05)$. Growing points did not increase markedly until the second spring when new shoots started to emerge from rhizomes formed from the taproot. The sward was dominated by summer grass (Digitaria sanguinalis (L.) Scop.) over the first summer, although an adequate density of $\mathrm{CC}$ plants remained beneath the canopy to provide good cover in the second season. By October 1995, new shoots from rhizomes extended approximately $20 \mathrm{~cm}$ from plant crowns, and reached up to $1 \mathrm{~m}$ from the original crown by the end of the second summer. A small-leaved local ecotype of WC became widely established in the $\mathrm{CC}$ as a weed contaminant but was increasingly dominated by $\mathrm{CC}$ during the second summer (mean herbage content of WC on mown CC plots 12 December 1995, 24\%; 1 May 1995, 9.5\%). While CC growth strengthened over the second season patches of weaker growth appeared in WC plots from late spring and became progressively larger during summer.

\section{Nitrogen fixation}

Both WC and CC established large vigorous rhizobial nodules and few plants failed to nodulate. $\mathrm{N}$-fixation activity generally mirrored growing point numbers, with levels in CC significantly below those of WC on all assessments after December $1994(\mathrm{P}<0.05$; Figure 1). However, WC N-fixing activity began to decline relative to growing point density from November 1995, coinciding with an increase in response to nematicide application (Figure 3b). This is consistent with earlier findings of nematicide application markedly improving $\mathrm{N}$-fixation activity in WC (Watson et al. 1994). WC lost its tap-root system between May and October 1995 and continued to produce from shallower stolon roots. 
Figure 1 (a) Growing point density (no/m $\mathrm{m}^{2}$ ) and (b) N-fixing activity ( $\mathrm{kg} \mathrm{N} / \mathrm{ha} /$ day) for white and caucasian clover pastures sown in September 1994. Vertical bars are SED.
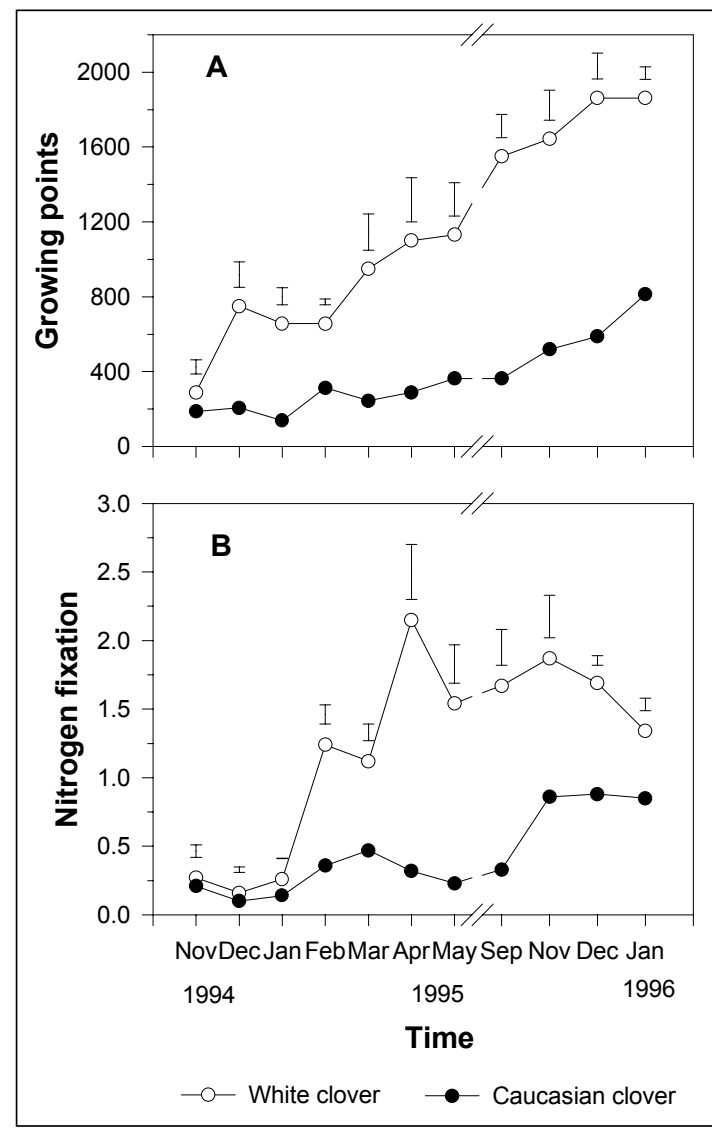

CC maintained a healthy tap-root, with a larger proportion of nodules below the $7.5 \mathrm{~cm}$ standard sampling depth used for $\mathrm{N}$-fixation determination. Thus $\mathrm{N}$-fixation activity may have been under-represented in $\mathrm{CC}$, relative to WC. However, nodule $\mathrm{N}$-fixing efficiency measured in April 1995 was 40\% greater for WC nodules than for CC (WC $4.26 \pm 0.36$ and CC $3.05 \pm 0.40 \mathrm{mg} \mathrm{N} /$ $\mathrm{mg}$ nodule DW/day).

\section{Pasture growth rate}

Kopu WC pasture had significantly greater growth rates than $\mathrm{CC}$ pastures for each harvest in the first growing season to June $1995(\mathrm{P}<0.05$; Figure 2$)$. Autumn growth for $\mathrm{WC}$ peaked at $30 \mathrm{~kg} \mathrm{DM} / \mathrm{ha} /$ day, whereas a considerable contribution to $\mathrm{CC}$ pasture yield was from summer grass. Early spring pasture growth rates reflected the cool season activity of Kopu WC and winter dormancy of CC (September and October, $\mathrm{P}<0.001$ ), with growth rates of $\mathrm{CC}$ pasture approximately 17 days
Figure 2 Total growth rates of white and caucasian clover pasture plots from April 1995-June 1996 after sowing in September 1994. Vertical bars are SED.

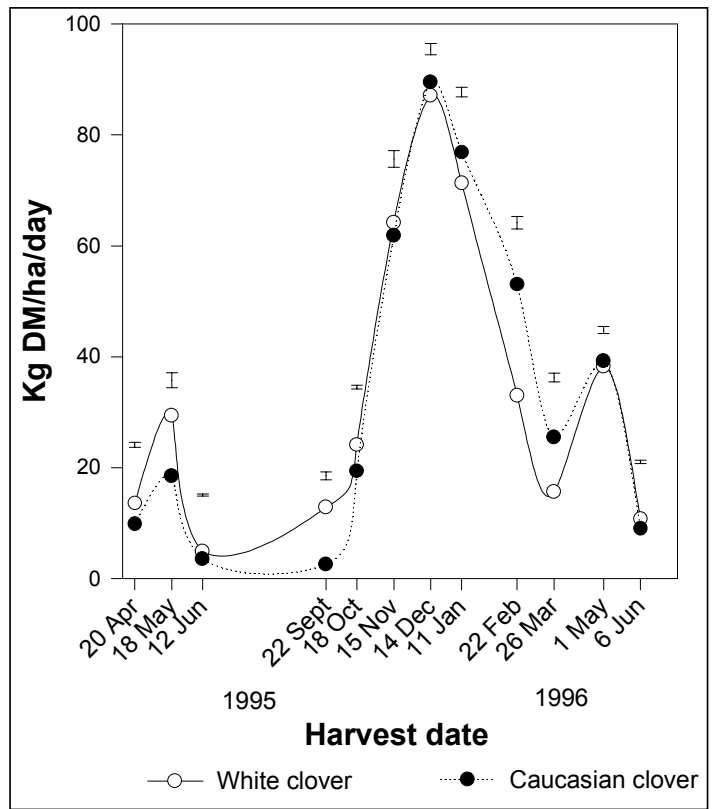

behind WC pasture on 22 September. By mid November, pasture growth rates for the two clover species were similar, and from December CC held better into summerearly autumn than WC, with $60 \%$ greater growth for February and March harvests $(\mathrm{P}<0.001)$. WC had a more pronounced autumn growth peak than $\mathrm{CC}$, largely contributed from ryegrass, but the decline in growth rate after May was similar. Herbage yield over the whole of the second growing season (September-June) was $9 \%$ greater for CC than for WC (11858 v $10883 \mathrm{~kg} \mathrm{DM} /$ ha; $\mathrm{P}<0.01)$.

\section{Yield responses}

Lack of randomisation between the pure clover and ryegrass undersown plots invalidates a statistical comparison of with and without ryegrass main effects (Figure 3). Ryegrass did not make a major contribution to total yields until autumn 1996 (Figure 3a). A yield decrease in September resulted from drilling damage to the pasture. Ryegrass also had a negative impact in February when a marginal soil moisture deficit decreased yield more on mixed species plots than on pure clover. In particular, some wilting and loss of WC was observed on ryegrass plots which had not been treated with nematicide. The loss of WC was followed by an increased presence of summer grass (clover species $\times$ nematicide interaction for summer grass and WC content in March 
$\mathrm{P}<0.05$ ). By March 1996 ryegrass content was greater on undersown WC (53\% of herbage DM) than on the undersown $\mathrm{CC}$ plots $(29 \%$; $\mathrm{P}<0.01)$.

Nematicide had no effect on herbage yield over the first growing season. September 1995 application of nematicide had a phytotoxic effect on October yields $(\mathrm{P}<0.05$; Figure $3 \mathrm{~b})$. Thereafter WC showed a progressive increase in yield response to nematode control, reaching $87 \%$ by June $(\mathrm{P}<0.001)$. A reduced response in May reflected the contribution by maturing summer grass particularly on untreated WC plots. CC was much slower to respond to nematicide, but gave increasing responses from February, reaching $32 \%$ in June $(\mathrm{P}<0.05)$. The accumulated yield from September-June was increased by $18 \%$ for $\mathrm{WC}(\mathrm{P}<0.001)$ and $3.3 \%$ for $\mathrm{CC}$ (ns).

WC growth in October increased $34 \%$ as a result of fungicide treatment applied in September, but CC was unaffected (clover $\times$ fungicide interaction $\mathrm{P}<0.001$; Figure $3 \mathrm{c}$ ). Subsequent responses remained below $10 \%$ for both clover species. Fungicide increased the accumulated yield by $6.3 \%$ for $\mathrm{WC}(\mathrm{P}<0.001)$ and $2.4 \%$ for CC. An apparent negative response in autumn for $\mathrm{CC}(\mathrm{P}=0.053)$ may have resulted from the effect of a small increase in $\mathrm{CC}$ vigour through summer reducing ryegrass content (clover species $\mathrm{x}$ undersowing interaction for ryegrass yield in March, $\mathrm{P}<0.01$ ).

When compared over the whole season, differences between $\mathrm{CC}$ and $\mathrm{WC}$ yields were smallest when nematicide and ryegrass occurred together. This result can be explained by the greater response of WC to nematicide treatment and by the higher level of ryegrass associated with WC. The effects of nematicide and fungicide treatments were additive.

\section{Nematode and insect pests}

The main clover nematode pests, clover cyst (Heterodera trifolii Goffart) and root knot (Meloidogyne hapla (Chitwood)), were present at very low levels after maize but subsequently increased to high populations in some patches. Clover cyst nematode increased more rapidly under WC (only $5 \%$ of total cyst nematodes from sequential sampling were from CC), while root knot nematodes increased more evenly (64\% sampled from $\mathrm{CC})$. Root knot nematode was found at $1 \mathrm{~m}$ depth in association with $\mathrm{CC}$ tap-roots. A root-lesion nematode (Pratylenchus crenatus Loof), which is hosted by both grasses and clovers, was less numerous in association with CC ( $28 \%$ of total sampled) but most of the remainder were found on two of the four WC plots. Seedling roots of both clovers were invaded by the root-lesion nematode.

Of the soil dwelling insect pests, grass grub (Costelytra zealandica (White)) and Tasmanian grass
Figure 3 The main-effect response in DM yields (\% increase for all plots with a treatment over all plots without that treatment) for (a) ryegrass undersowing, (b) nematicide and (c) fungicide treatments in second year plots of white and caucasian clover pasture.

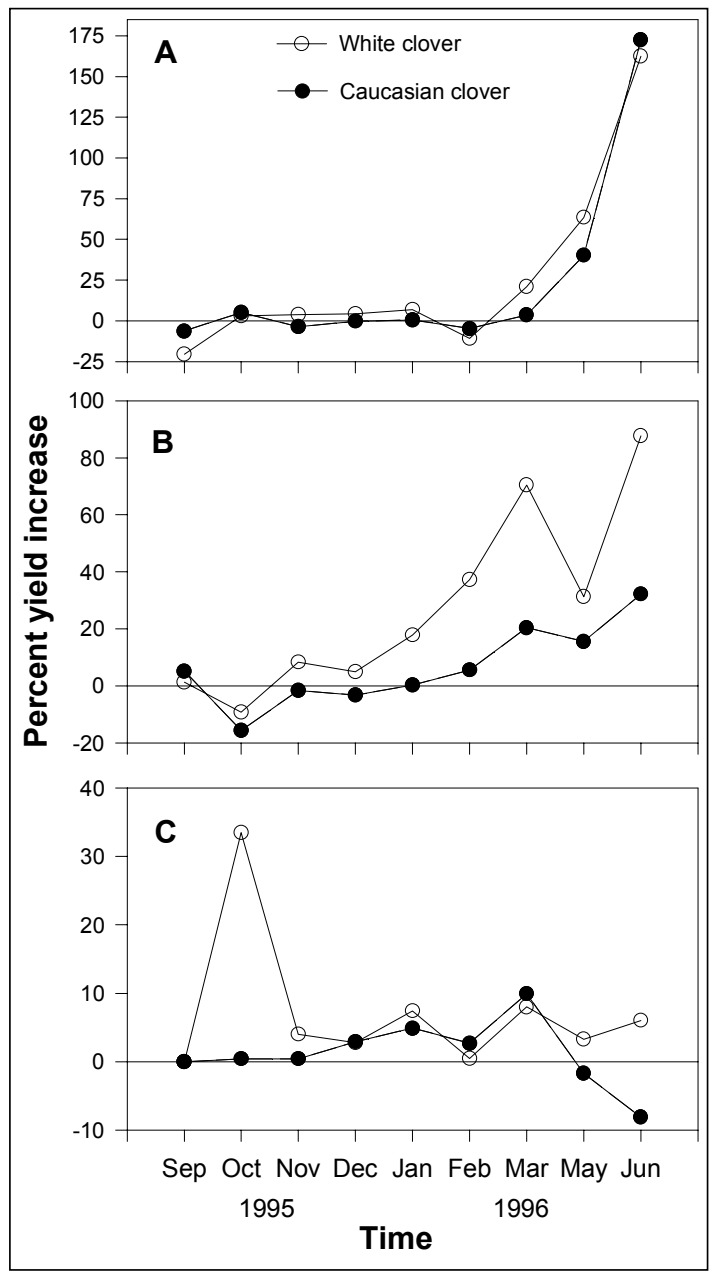

grub (Aphodius tasmaniae Hope) increased most rapidly, with less present under CC (Watson et al. 1996b). Populations levels in autumn 1996 (196 and $286 / \mathrm{m}^{2}$, $\mathrm{P}<0.05 ; 40$ and $79 / \mathrm{m}^{2}, \mathrm{P}<0.001$ for each pest on $\mathrm{CC}$ and $\mathrm{WC}$ respectively) were unlikely to have reached peak numbers within 2 years of pasture establishment. Two species of Lepidoptera were the most prevalent foliar feeding pests, consuming up to $26 \%$ of leaf area on WC during late summer. Larvae of the common blue butterfly (Zizina labradus (Godt.)) was more prevalent on WC, and larvae of the small native moth (Epyaxa rosearia Doubleday) was the most common defoliator of CC (Watson et al. 1996b). This is the first time $E$. 
rosearia has been implicated as a pest of pasture legumes.

\section{Discussion}

In many comparative studies $\mathrm{CC}$ has received common management with other pasture legumes, with no concession for the slow first year growth of CC. The aim in this trial was to provide for optimum $\mathrm{CC}$ establishment by sowing as pure species into a seed-bed after cereal cropping. In this way Endura $\mathrm{CC}$ matched production of Kopu WC by mid way through the second spring and gave superior production during the second summer. Production in the second season was comparable to that reported for mature CC in a nonirrigated lowland pasture in Canterbury (Daly \& Mason 1987). Summer conditions for 1995-96 were exceptionally good for pasture growth by coastal Bay of Plenty standards, but the indications were that WC would have been affected relatively more adversely by a drier summer.

Superior performance by CC was based partly around better tolerance of pests and diseases. CC is resistant to several virus diseases affecting $\mathrm{WC}$, including alfalfa mosaic virus (Pederson \& McLaughlin 1989). This virus became widely evident in Kopu WC from spring 1995. The reaction of CC to nematodes has not been reported except as a favoured host for the rootlesion nematode (Pratylenchus penetrans (Cobb) Filipyev and Schur-Stekoven), which did not affect growth of WC or CC in limited testing (Thies et al. 1995). This species occurs in New Zealand pasture along with other species of the genus.

Excessive grass competition in the first year can delay the time $\mathrm{CC}$ takes to make a useful contribution by 2-4 years (Anon, undated; Moorhead et al. 1994). In this trial summer grass dominated $\mathrm{CC}$ in the first summer after establishment as pure species pasture. Although the grass cover may have prevented harmful soil surface temperatures (Watson et al. 1996a), sowing with a light rate of a desirable grass species may have been preferable. Several other pasture options using $\mathrm{CC}$ are also possible. CC may serve as a special purpose alternative to lucerne for quality summer dairy forage or conservation. It may be advantageous to establish $\mathrm{CC}$ and WC together, combining the ability of WC to provide early cover with $\mathrm{CC}$ to persist after the decline in WC vigour. Further evaluation of CC is needed to confirm its long-term persistence, performance and reaction to pests and diseases in northern environments. $\mathrm{CC}$ may provide a means to extend peak summer milk flow, which WC forage is capable of producing (Rogers \& Robertson 1984), but frequently fails to deliver in summer-autumn pasture.

\section{Conclusions}

When established in cultivated ground after cereal cropping, CC sown in spring matched WC growth rates by mid spring of the following year and exceeded WC yields in the second growing season in the Bay of Plenty.

The advantage gained by CC over WC was derived in large part from reduced impacts of pests and diseases, particularly nematodes, which increasingly affected WC performance from the second summer.

Summer production from CC may provide a means to extend the summer milk flow above that from WCbased pasture, but winter dormancy would need to be accommodated.

The longer-term performance and persistence of CC in northern dairying environments needs to be confirmed.

\section{ACKNOWLEDGEMENTS}

Margaret and Rex Benner, Pongakawa, for generously hosting this study; Bay Milk Products Ltd and its Coastal Producer Group for their support and interest; Wrightson Ltd for providing pelleted inoculated clover seed; Bay of Plenty Fertiliser Ltd for sponsoring fertiliser management; Catherine Cameron and Dr Neil Cox for statistical analyses; Karen Knight, MAFQual, Lincoln and Chris Mercer, AgResearch, Palmerston North for identification of Pratylenchus and Meloidogyne species respectively; and FRST for research funding.

\section{REFERENCES}

Anon. Endura clover: management package. Wrightson Seeds Ltd, Kimihia Research Centre.

Brock, J.L. 1988. Evaluation of New Zealand bred white clover cultivars under rotational grazing and set stocking with sheep. Proceedings of the New Zealand Grassland Association 49: 203-206.

Daly, G.T.; Mason, C.R. 1987. Performance of Caucasian and zigzag clovers. Proceedings of the New Zealand Grassland Association 48: 151-156.

Hoglund, J.H.; Brock, J.L. 1978. Regulation of nitrogen fixation in a grazed pasture. New Zealand journal of agricultural research 7: 45-51.

Moorhead, A.J.E.; White, J.G.H.; Jarvis, P.; Lucas, R.J.; Sedcole, J.R. 1994. Effect of sowing method and fertiliser application on establishment and first season growth of caucasian clover. Proceedings of the New Zealand Grassland Association 56: 91-95.

Pederson, G.A.; McLaughlin, M.R. 1989. Resistance to viruses in Trifolium interspecific hybrids related to white clover. Plant disease 73: 997-999. 
Pederson, G.A.; Windham, G.L.; Ellsbury, M.M.; McLaughlin, M.R.; Pratt, R.G.; Brink, G.E. 1991. White clover yield and persistence as influenced by cypermethrin, benomyl and root knot nematode. Crop science 31: 1297-1302.

Peterson, P.R.; Sheaffer, C.C.; Jordan, R.M.; Christians, C.J. 1994. Responses of Kura clover to sheep grazing and clipping: 1. Yield and forage quality. Agronomy journal 86: 655-660.

Riley, A.J. 1979. Re-establishing pastures a Waikato problem. New Zealand fertiliser journal No. 54: 8 9.

Rogers, G.L.; Robinson, I.B. 1984. Whole lactation production of cows grazing white clover or perennial ryegrass. Dairy production research report: Ellinbank and Kyabram. pp. 148-149.

Thies, J.A.; Petersen, A.D.; Barnes, D.K. 1995. Host suitability of forage grasses and legumes for rootlesion nematode Pratylenchus penetrans. Crop science 35: 1647-1651.
Virgona, J.M.; Dear, B.S. 1996. Comparative performance of caucasian clover (Trifolium ambiguum cv. Monaro) after 11 years under lowinput conditions in south-eastern Australia. New Zealand journal of agricultural research 39: 245253.

Watson, R.N.; Bell, N.L.; Neville, F.J.; Harris, S.L. 1994. Improving pasture sustainability by reducing the impact of clover nematodes. pp. 83-85. In: Pankhurst, C.E. (ed.). Soil Biota: Management in Sustainable Farming Systems. Australia: CSIRO.

Watson, R.N.; Harris, S.L.; Bell, N.L.; Neville, F.J. 1996a. Deferred grazing to enhance white clover content in pastures (abstract). Agronomy Society of New Zealand Special Publication No. 11: 154.

Watson, R.N.; Neville, F.J.; Bell, N.L. 1996b. Insect pests associated with white and caucasian clover in a Bay of Plenty dairy pasture. Proceedings of the New Zealand Plant Protection Conference 49: 234 238. 